2011 年志方メダル受賞記念総合論文

Award Integrated Research Paper Article,

2011 Shikata Medal

\title{
Kinetic Studies on Enzymatic Hydrolysis of Polysaccharides by Amperometric Biosensors
}

\author{
Hirosuke Tatsumi \\ International Young Researchers Empowerment Center, Shinshu University, \\ Matsumoto, Nagano 390-8621, Japan
}

Received June 29, 2012; Accepted after Peer-Review July 26, 2012

\begin{abstract}
Kinetics of the enzymatic hydrolysis of insoluble polysaccharides has been studied by using amperometric biosensors. The hydrolysis of starch, cellulose, chitin, and chitosan, catalyzed by glucoamylase, cellobiohydrolase, chitinase, and chitosanase, respectively, has been successfully monitored by direct and continuous measurements of their products in thick suspensions without any influence of turbidity. The dependence of the hydrolytic rates on the enzyme concentration as well as on the amount and specific surface area of polysaccharides can be explained by the rate equation based on the Langmuir adsorption of free enzymes onto the surface of polysaccharides.
\end{abstract}

Keywords: biosensors, glycoside hydrolases, starch, cellulose, chitin/chitosan

\section{Introduction}

Electrochemical measurements have an advantage of being free from the influence of turbidity and coloration of a test solution. In previous studies, electrochemical sensors have been successfully applied to analyses of turbid samples; including blood, foods, and bacterial cell suspensions. ${ }^{1)}$ This advantage makes the electrochemical measurements suitable also for the monitoring of enzymatic reactions with insoluble substrates such as polysaccharides and lipids. In recent years, we have introduced amperometric biosensors into the kinetic study of enzymatic hydrolysis of insoluble polysaccharides such as starch and cellulose, based on direct and continuous measurements of saccharides produced in thick suspensions. The methods and the experimental results are summarized in this article.

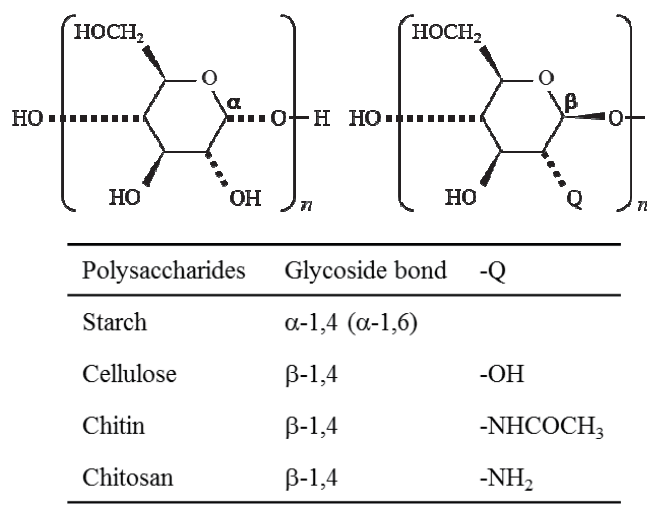

Scheme 1. Structure of the polysaccharides. 
Table 1. Hydrolytic enzymes in this study.

\begin{tabular}{llll}
\hline Enzymes & Substrates & Hydrolysis & Products \\
\hline $\begin{array}{l}\text { Glucoamylase } \\
\text { (GA) }\end{array}$ & Starch & $\alpha-1,4$ (exo) & $\beta$-D-Glucose \\
$\begin{array}{l}\text { Cellobiohydrolase } \\
(\mathrm{CBH})\end{array}$ & Cellulose & $\beta-1,4$ (exo) & $\beta$-Cellobiose \\
Chitinase & Chitin & $\beta-1,4$ (endo) & $\begin{array}{l}\text { Chitin } \\
\text { oligosaccharides }\end{array}$ \\
Chitosanase & Chitosan & $\beta-1,4$ (endo) & $\begin{array}{l}\text { Chitosan } \\
\text { oligosaccharides }\end{array}$ \\
\hline
\end{tabular}

Table 2. Redox enzymes for biosensors.

\begin{tabular}{|c|c|c|}
\hline Enzymes & Substrates & Electron Acceptors \\
\hline $\begin{array}{l}\text { Glucose oxidase } \\
\text { (GOx) }\end{array}$ & $\beta$-D-Glucose & $\begin{array}{l}\mathrm{O}_{2} \text {, quinones, and } \\
\text { some other acceptors }\end{array}$ \\
\hline $\begin{array}{l}\text { PQQ-dependent glucose } \\
\text { dehydrogenase (PQQ-GDH) }\end{array}$ & $\begin{array}{l}\text { Various mono- and } \\
\text { oligo-saccharides }\end{array}$ & $\begin{array}{l}\text { Quinones and some } \\
\text { other acceptors }\end{array}$ \\
\hline $\begin{array}{l}\text { Cellobiose dehydrogenase } \\
(\mathrm{CDH})\end{array}$ & $\begin{array}{l}\beta \text { - }(1 \rightarrow 4) \text {-bonded } \\
\text { oligosaccharides }\end{array}$ & $\begin{array}{l}\text { Quinones and some } \\
\text { other acceptors }\end{array}$ \\
\hline$N$-acylhexosamine oxidase & $N$-acylhexosamine & $\mathrm{O}_{2}$ \\
\hline
\end{tabular}

Scheme 1 shows the structure of the polysaccharides used in this study. Also, the hydrolytic enzymes and the redox enzymes used for biosensors are summarized in Tables 1 and 2, respectively.

\section{Hydrolysis of starch}

Glucoamylase (GA) is a glycoside hydrolase which produces glucose from the non-reducing ends of starch. In recent years, some GAs capable of direct hydrolysis of starch granules have received considerable attention, as their potential value for certain biotechnological applications, such as the production of ethanol ${ }^{2)}$ or lactic acid $^{3)}$ from a starchy biomass, was recognized. In most of previous studies, the hydrolysis has been monitored by spectrophotometric detection of glucose, after removing starch granules at different reaction times. ${ }^{4)}$ In contrast to spectrophotometry, electrochemical measurements can provide direct and continuous monitoring of the hydrolysis without the influence of turbidity. We have employed an amperometric glucose biosensor to study the kinetics of enzymatic hydrolysis of starch granules by GA in a thick starch suspension. ${ }^{5-7)}$

A glucose oxidase (GOx)-immobilized benzoquinone (BQ)-mixed carbon paste electrode was prepared as described by Ikeda et al (Fig. 1). ${ }^{8,9)}$ In this study, graphite powder containing $25 \mathrm{wt} \%$ liquid paraffin and $8 \mathrm{wt} \% \mathrm{BQ}$ was packed into a carbon paste electrode holder. A $10-\mu \mathrm{L}$ aliquot of 3 $\mathrm{U} \mu \mathrm{L}^{-1}$ GOx solution was dropped onto the surface of the BQ-mixed carbon paste electrode of geometrical area $0.071 \mathrm{~cm}^{2}$. The solvent was allowed to evaporate and then the electrode surface was covered with a dialysis membrane (cut-off molecular weight of 12000-14000, 20- $\mu \mathrm{m}$ thick in the dry state). The electrode was covered by a nylon net to give it physical strength. The reaction scheme of this glucose biosensor is shown in Fig. 2. When glucose is present in the test solution, BQ in the vicinity of the electrode surface is reduced by the GOx reaction to produce hydroquinone. Hydroquinone is then oxidized at the applied potential of $+0.60 \mathrm{~V}$ vs. $\mathrm{Ag}|\operatorname{AgCl}| 0.1 \mathrm{M} \mathrm{KCl}$ reference electrode, and thus a steady-state current (I), which is determined kinetically by the rate of the GOx reaction, can be observed. The biosensor allowed determination of glucose sensitive to levels as low as $0.01 \mathrm{mM}$ with a linearity of up to $10 \mathrm{mM}$. The response time was approximately $20 \mathrm{~s}$.

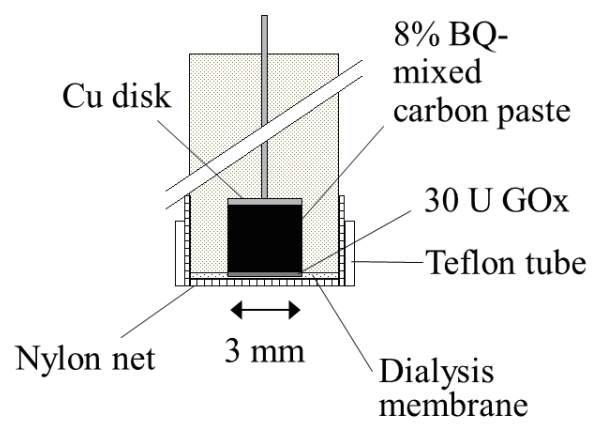

Fig. 1. Cross-sectional view of the GOximmobilized BQ-mixed carbon paste electrode. 


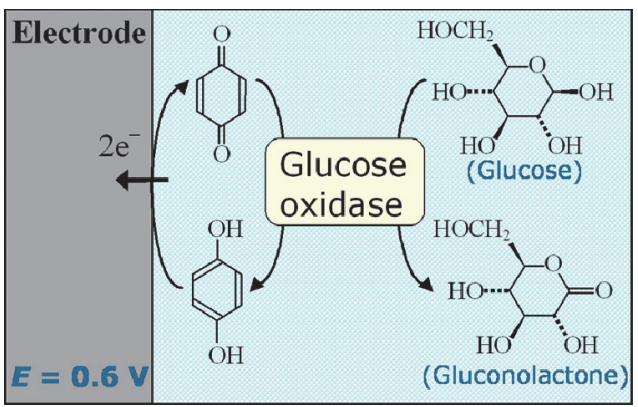

Fig. 2. Reaction scheme of the GOx-immobilized BQ-mixed carbon paste electrode.

Curves A and B of Fig. 3 show the current $(I)$-time $(t)$ curve for the production of glucose in a $0.25 \mathrm{mg} \mathrm{mL}^{-1}$ soluble starch solution and a $0.020 \mathrm{~g}$ $\mathrm{mL}^{-1}$ raw corn starch suspension, respectively, at $25{ }^{\circ} \mathrm{C}$ and $\mathrm{pH}$ 5.0. While the current reached a constant value within a couple of minutes after addition of $2 \mathrm{U} \mathrm{mL}^{-1} \mathrm{GA}$ into the soluble starch solution (curve A), the current increased linearly upon addition of GA into the raw starch suspension (curve B).

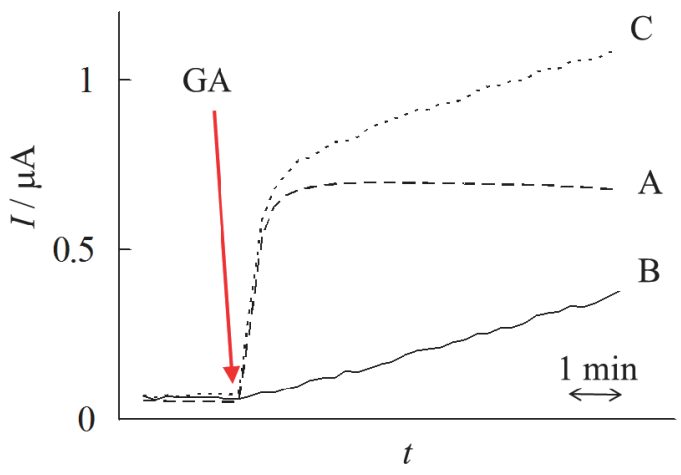

Fig. 3. $I-t$ curve for the production of glucose. Measurements were carried out in $0.1 \mathrm{M}$ acetate buffer (pH 5.0) containing (A) $0.25 \mathrm{mg} \mathrm{mL}^{-1}$ soluble starch, (B) $0.020 \mathrm{~g} \mathrm{~mL}^{-1}$ raw corn starch, or (C) both. GA (2 U $\mathrm{mL}^{-1}$ ) was added at the point indicated by the arrow. The sensitivity of the glucose biosensor was $0.47 \mu \mathrm{A}$ $\mathrm{mM}^{-1}$. (Reprinted with permission from Ref. 6 . Copyright 2005, American Chemical Society.)
When the supernatant of the suspension was used for the measurement, the current did not change by addition of GA. The results indicate that the dissolution of raw starch into the bulk solution was negligible and that the current increase of curve $\mathrm{B}$ can be attributed to the production of glucose by the surface hydrolysis of raw starch by GA. Curve $\mathrm{C}$ of Fig. 3 shows the $I-t$ curve when both soluble starch $\left(0.25 \mathrm{mg} \mathrm{mL}^{-1}\right)$ and raw starch $\left(0.020 \mathrm{~g} \mathrm{~mL}^{-1}\right)$ were used. Upon addition of GA, the current increased in the same way as curve A and then linearly with the same slope as curve B, indicating that the rate $(v)$ of the surface hydrolysis of raw starch by GA can be determined, even if the suspension contains soluble starch.

Figure 4 shows the plot of the $v$ value against the free enzyme concentration $\left(\left[\mathrm{E}_{\mathrm{f}}\right]\right)$ obtained with the starch suspension at the substrate amount per volume $(S)$ of $0.010 \mathrm{~g} \mathrm{~mL}^{-1}$. The $v$ value increased with increasing $\left[\mathrm{E}_{\mathrm{f}}\right]$ to approach a saturation value. The dependence of $v$ on $\left[\mathrm{E}_{\mathrm{f}}\right]$ can be explained by the rate equation derived from a three-step mechanism, (i) Langmuir adsorption of the free enzyme onto the surface of the substrate, (ii) reaction of the adsorbed enzyme with substrate, and (iii) liberation of the product (see Appendix for details):

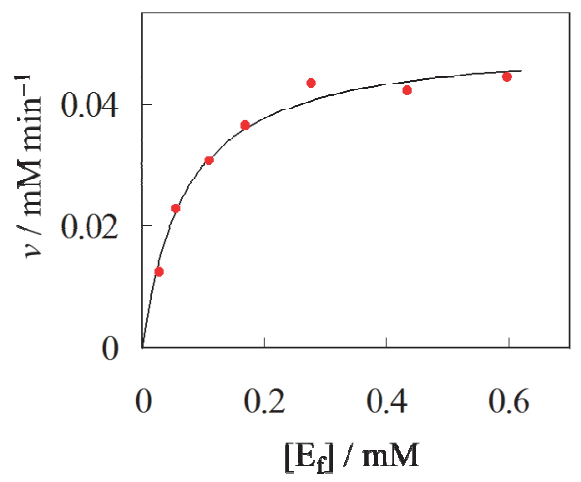

Fig. 4. Dependence of $v$ on $\left[\mathrm{E}_{\mathrm{f}}\right]$ obtained at $S=0.010 \mathrm{~g}$ $\mathrm{mL}^{-1}$. Solid line is calculated by Eq. 1 using the $\beta$ and $v_{\max }$ values given in the text. (Reprinted with permission from Ref. 6. Copyright 2005, American Chemical Society.) 


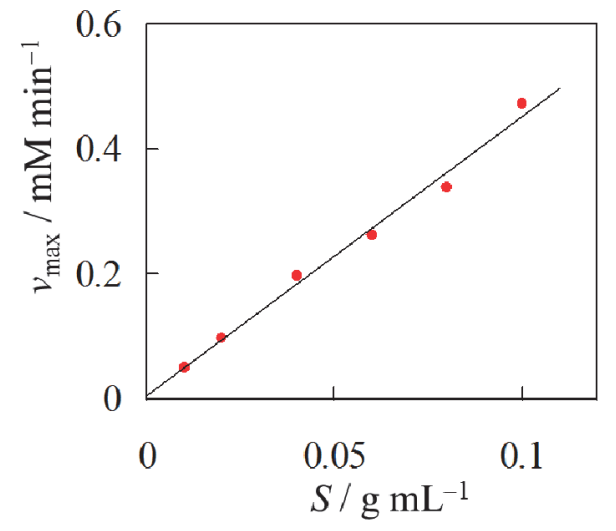

Fig. 5. Dependence of $v_{\max }$ on $S$ at $\left[\mathrm{E}_{\mathrm{f}}\right]>\beta^{-1}$. (Reprinted with permission from Ref. 6. Copyright 2005, American Chemical Society.)

$$
v=\frac{v_{\max } \beta\left[\mathrm{E}_{\mathrm{f}}\right]}{1+\beta\left[\mathrm{E}_{\mathrm{f}}\right]}
$$

with

$$
v_{\max }=k_{0} \Gamma_{\max } a S,
$$

where $\beta$ is the adsorption coefficient, $k_{0}$ is the molecular activity of the adsorbed enzyme, $\Gamma_{\max }$ is the saturation value of the adsorbed amount per unit area, and $a$ is the specific surface area of substrate, which can be calculated by Eq. (A12). In Fig. 4, the solid line is the fitted curve by Eq. 1 , giving $\beta=$ $(1.4 \pm 0.4) \times 10^{7} \mathrm{M}^{-1}$ and $v_{\max }=0.051 \pm 0.005 \mathrm{mM}$ $\min ^{-1}$, respectively. The $\beta$ value obtained here is in good agreement with $\beta=(1.6 \pm 1.3) \times 10^{7} \mathrm{M}^{-1}$, obtained from the Langmuir isotherm of GA on the substrate surface by the spectrophotometric determination of the decrease in $\left[\mathrm{E}_{\mathrm{f}}\right]$. Figure 5 shows the plot of the $v_{\max }$ value against $S$ obtained by the measurement at $\left[\mathrm{E}_{\mathrm{f}}\right] \gg \beta^{-1}$. The $v_{\max }$ was proportional to $S$ in the range tested, which is consistent with the prediction from Eq. 2. From the slope of the regression line in Fig. 5, $k_{0}$ was calculated to be $6.3 \pm 1.7 \mathrm{~s}^{-1}$. Also, the $v_{\max }$ value was obtained for classified starch granules with different particle sizes at a constant $S$ value. The $v_{\max }$ was proportional to $a$, and the regression line gave $k_{0}=$
$6.1 \pm 3.1 \mathrm{~s}^{-1}$. These $k_{0}$ values appear to be somewhat smaller than $24 \pm 1 \mathrm{~s}^{-1}$, reported by Hiromi et al. as the molecular activity of GA for the hydrolysis of maltodextrin (average degree of polymerization of 15.5) at $\mathrm{pH} 4.5,{ }^{10)}$ suggesting that insoluble substrate is to some extent unfavorable for the formation of a productive complex as compared with soluble substrate, probably due to the inaccessibility of the non-reducing end of starch to the catalytic site of GA. By using the $k_{0}$ values obtained above and the intrinsic rate constant of GA for the hydrolysis of glycoside linkage in a productive complex, ${ }^{10)}$ we estimated that 1 out of 12 adsorbed GA molecules formed a productive complex at the steady state.

We have extended the work to the hydrolysis of starch granules from various botanical sources (rice, wheat, cassava, sweet potato, and potato), and discussed the $k_{0}$ values in relation to the crystalline structure of the granules. ${ }^{7}$ )

\section{Hydrolysis of cellulose}

Nowadays, efficient enzymatic hydrolysis of cellulose or cellulosic materials is becoming a key challenge in the production of biofuels and biomaterials from biomass. Cellobiohydrolase $(\mathrm{CBH})$ is a cellulase which degrades cellulose to release cellobiose from the chain ends. The enzyme from the potent cellulolytic fungi of Trichoderma species has been extensively investigated by many researchers, because it has high specific activity for crystalline cellulose. ${ }^{11)}$ Although considerable progress toward an understanding of the structure-function relationship of $\mathrm{CBH}$ has been made in recent years, very few reports exist on quantitative kinetic analyses of the enzymatic hydrolysis of crystalline cellulose, because it has been difficult to achieve a direct kinetic measurement of the biphasic system with the insoluble cellulose and the soluble $\mathrm{CBH} .{ }^{11,12)}$

Amperometic biosensors are useful also for the 
kinetic measurement of the hydrolysis of cellulose by $\mathrm{CBH}$. To measure the concentration of cellobiose in a cellulose suspension with high sensitivity, we constructed a biosensor with pyrroloquinoline quinone-dependent glucose dehydrogenase (PQQ-GDH). ${ }^{13)}$ PQQ-GDH has low substrate specificity and can use not only glucose but also disaccharides such as cellobiose as the substrates with comparable activity. By the use of the PQQ-GDH-immobilized biosensor, direct and continuous monitoring of the hydrolysis can be achieved even in a thick crystalline cellulose suspension. The experimental results of the kinetic measurements can be explained by the rate equation derived from a three-step mechanism, which is analogous to that of the enzymatic hydrolysis of starch granules.

Recently, we have employed cellobiose dehydrogenase $(\mathrm{CDH})$ in place of PQQ-GDH. ${ }^{14-16)}$ This enzyme is specific to $\beta$ - $(1 \rightarrow 4)$-bonded disaccharides and longer oligosaccharides, and has essentially no activity to monosaccharides including glucose. This enables us to determine the concentration of cellobiose by the biosensor with $\mathrm{CDH}$, even when glucose is present in the reaction mixture. In addition, we have improved the biosensor to make the response faster by modifying the procedure for immobilizing $\mathrm{CDH}^{15}{ }^{15}$ The dynamic delay of the biosensor was about $1 \mathrm{~s}$, indicating that kinetic measurements could be performed accurately for reaction times of $\sim 10 \mathrm{~s}$. Also, we have estimated the influence of the mutarotation of cellobiose on the measurements ${ }^{15}$. By using this biosensor, we have measured the cellobiose concentration continuously at the initial stage $(<1 \mathrm{~min})$ of the hydrolysis. $\left.{ }^{16}\right)$ Based on the results, we discussed the pre-steady state kinetics of the $\mathrm{CBH}$ reaction, and concluded that slow dissociation of inactive-enzyme-cellulose complexes governs the hydrolytic rate at pseudo-steady state.

\section{Hydrolysis of chitin and chitosan}

Chitin and chitosan are $\beta$-( $1 \rightarrow 4)$-bonded polysaccharides of $N$-acetylglucosamine and glucosamine, respectively, and usually found together in natural resources such as fungal cell walls and invertebrate cuticles. The hydrolysis products, i. e., their monomers and oligomers, have attracted considerable attention due to their potential antibacterial, anticancer, or elicitor activity. ${ }^{17)}$ So far, the activity of the glycoside hydrolases chitinase and chitosanase has been assayed by the detection of amino sugars released in the reaction mixture. However, the boiling in alkaline solution and the treatment in acid solution in the assay protocols are troublesome and time-consuming. We have introduced an amperometric biosensor for the detection of amino sugars to the activity measurement of chitosanase. ${ }^{18)}$ To measure the concentration of amino sugars in a chitosan solution with high sensitivity, we employed an amperometic biosensor with PQQ-GDH, which had been constructed previously for cellobiose detection. PQQ-GDH has low substrate specificity and can use glucosamine and chitosan oligosaccharides as the substrates. By the use of the PQQ-GDH-immobilized biosensor, the activity measurement of chitosanase was very much simplified. Also, we devised an amperometric biosensor for the detection of $\mathrm{N}$-acetylglucosamine and chitin oligosaccharides using $N$-acylhexosamine oxidase, ${ }^{19)}$ and applied it to the activity measurement of chitinase. ${ }^{20)}$

\section{Conclusions}

Generally, glycoside hydrolases can be divided into two groups: exo-hydrolases cleave the glycoside bonds at the reducing or non-reducing ends of polysaccharide chains to produce mono- or di-saccharides, while endo-hydrolases randomly act on the glycoside bonds inside of polysaccharide chains. Amperometric biosensors are useful for the 
kinetic study of exo-hydrolases, because a single product can be determined selectively. If amperometic biosensors could be developed for other mono- or di-saccharides, such as mannose and xylose, it would be possible to apply the same method to exo-hydrolases of mannans, xylans, etc. On the other hand, biosensors do not give an accurate hydrolytic rate of endo-hydrolases, by which many different products are formed.

In industrial saccharification of starch and cellulose, however, exo- and endo-hydrolases are often used together to enhance the hydrolysis. The kinetic analysis has been desired for the synergetic effect of this two-enzyme system. In order to monitor the kinetics of both two enzymes, it is necessary to combine amperometric biosensors with another method, which measures the hydrolytic rate of endo-hydrolases. Isothermal microcalorimetry has recently shown promise as a continuous measurement method for the enzymatic degradation of polysaccharides. ${ }^{21,22)}$ This method is based on the quantification of the heat associated with the hydrolysis of glycoside bonds. Therefore, it gives the sum of the rates of exo- and endo-hydrolases, when the both are used together. In addition, it has the same advantage of being free from the turbidity or coloration of the test solution as electrochemical measurements. When these two methods are combined, we can expect that the two rates of the enzymatic hydrolysis can be determined at the same time. We are now extending our work to incorporate a small biosensor into a calorimetric cell for the kinetic analysis of the two-enzyme system. ${ }^{23)}$

\section{Acknowledgements}

The author would like to thank Prof. Tokuji Ikeda, Prof. Hajime Katano, Prof. Peter Westh, and Mr. Nicolaj Cruys-Bagger for their fruitful discussions. This study was performed through a Grant-in-Aid for Scientific Research from the Fukui Prefecture University Science Foundation,
Grants-in-Aid for Young Scientists (No. 16780086, 18780077, and 23760746), and Special Coordination Funds for Promoting Science and Technology of the Ministry of Education, Culture, Sports, Science and Technology, the Japanese Government.

\section{Appendix}

We consider the following three-step mechanism:

$$
\begin{aligned}
& \mathrm{E}_{\mathrm{f}} \rightleftharpoons \mathrm{E}_{\mathrm{ad}}, \\
& \mathrm{E}_{\mathrm{ad}}+\mathrm{S} \stackrel{k_{1}}{\rightleftarrows} \mathrm{E}_{\mathrm{ad}} \mathrm{S}, \\
& \mathrm{E}_{\mathrm{ad}} \mathrm{S} \stackrel{k_{2}}{\longrightarrow} \mathrm{E}_{\mathrm{ad}}+\mathrm{P},
\end{aligned}
$$

that is, the free, or unbound, enyzme $\left(E_{\mathrm{f}}\right)$ is adsorbed onto the surface of the substrate according to $\mathrm{Eq} . \mathrm{A} 1$, then the adsorbed enzyme $\left(\mathrm{E}_{\mathrm{ad}}\right)$ is bound with the substrate (S) to give a productive complex $\left(E_{a d} S\right)$ according to Eq. A2, which is followed by the liberation of the product $(\mathrm{P})$ according to Eq. A3. It should be noted that a so-called nonproductive complex is included by $\mathrm{E}_{\mathrm{ad}}$ for simplicity.

We assume the adsorption and desorption of Eq A1 are very fast processes so that the Langmuir adsorption isotherm is valid with respect to the concentration of $E_{f}\left(\left[E_{f}\right]\right)$ :

$$
\frac{\Gamma}{\Gamma_{\max }}=\frac{\beta\left[\mathrm{E}_{\mathrm{f}}\right]}{1+\beta\left[\mathrm{E}_{\mathrm{f}}\right]}
$$

where $\Gamma=\Gamma_{\text {Ead }}+\Gamma_{\text {Eads }}, \Gamma_{\text {Ead }}$ and $\Gamma_{\text {Eads }}$ being the adsorbed amount of $E_{a d}$ and $E_{a d} S$ per unit area, respectively; $\Gamma_{\max }$ is the saturation value of $\Gamma$; and $\beta$ is the adsorption coefficient. The rate equations for Eqs. A2 and A3 are given by, respectively,

$$
\frac{\mathrm{d} \Gamma_{\text {EadS }}}{\mathrm{d} t}=k_{1}^{\prime} \Gamma_{\text {Ead }}-\left(k_{-1}+k_{2}\right) \Gamma_{\text {EadS }}
$$

and

$$
\frac{\mathrm{d}[\mathrm{P}]}{\mathrm{d} t}=k_{2} \Gamma_{\text {Eads }} \frac{A}{V},
$$

where $[\mathrm{P}]$ is the concentration of $\mathrm{P}, A$ the surface area of the substrate, and $V$ the volume of the test 
solution. In the derivation of Eq. A5, the pseudo-first-order reaction with respect to $\mathrm{S}$ is assumed to be satisfied in the forward step of Eq. $\mathrm{A} 2$, so that the pseudo-first-order rate constant $\left(k_{1}{ }^{\prime}\right)$ is used here and in the following.

At steady state, the rate ( $v$ ) is given by

$$
v=\frac{\mathrm{d}[\mathrm{P}]}{\mathrm{d} t}=\frac{v_{\max } \beta\left[\mathrm{E}_{\mathrm{f}}\right]}{1+\beta\left[\mathrm{E}_{\mathrm{f}}\right]}
$$

with

$$
v_{\max }=k_{0} \Gamma_{\max } \frac{A}{V},
$$

where $k_{0}$ represents the molecular activity of the adsorbed enzyme, as given by

$$
k_{0}=\frac{k_{2}}{1+K_{\mathrm{m}}{ }^{\prime}}
$$

with

$$
K_{\mathrm{m}}{ }^{\prime}=\frac{k_{-1}+k_{2}}{k_{1}^{\prime}} .
$$

The dimensionless parameter $K_{\mathrm{m}}{ }^{\prime}$ in Eq. A10 can be equated to the ratio of $\Gamma_{\text {Ead }}$ to $\Gamma_{\text {Eads }}$ at the steady state. The term of $A / V$ in Eqs. A6 and A8 is related to the specific surface area of the substrate $(a)$ and the weight of the substrate per volume $(S)$ by $A / V=$ $a S$, so that $v_{\max }$ is also given by

$$
v_{\text {max }}=k_{0} \Gamma_{\text {max }} a S .
$$

Assuming that substrate is spherical particles with a constant density $(\rho)$ and with various diameters $(d)$, the $a$ value can be related to $\rho$ and $d$ by

$$
a=\frac{6}{\rho} \frac{\Sigma d^{2}}{\Sigma d^{3}},
$$

where $\Sigma d^{2}$ and $\Sigma d^{3}$ are the sum of $d^{2}$ and $d^{3}$, respectively, of a given amount of substrate. These values can be determined from the size distribution of the particles.

\section{References}

1) “バイオ電気化学の実際 — バイオセンサ・ バイオ電池の実用展開— (Practical Bioelectrochemistry, Recent Developments in Biosensors \& Biofuel Cells, in Japanese)", ed. T.
Ikeda, CMC Publishing, Tokyo, 2007, and references cited therein.

2) H.-R. Kim, Y.-K. Im, H.-M. Ko, J.-E. Chin, I.-C. Kim, H. B. Lee, and S. Bai, Raw starch fermentation to ethanol by an industrial distiller's yeast strain of Saccharomyces cerevisiae expressing glucoamylase and $\alpha$-amylase genes, Biotechnol. Lett., 33, 1643 (2011).

3) R. P. John, G. S. Anisha, K. Madhavan Nampoothiri, and A. Pandey, Direct lactic acid fermentation: Focus on simultaneous saccharification and lactic acid production, Biotechnol. Adv., 27, 145, (2009).

4) A. C. Dona, G. Pages, R. G. Gilbert, and P. W. Kuchel, Digestion of starch: In vivo and in vitro kinetic models used to characterise oligosaccharide or glucose release, Carbohydrate Polymers, 80, 599 (2010).

5) H. Tatsumi and H. Katano, Kinetic analysis of enzymatic hydrolysis of raw starch by glucoamylase, Chem. Lett., 33, 692 (2004).

6) H. Tatsumi and H. Katano, Kinetics of the surface hydrolysis of raw starch by glucoamylase, J. Agric. Food Chem., 53, 8123 (2005).

7) H. Tatsumi, H. Katano, and T. Ikeda, Kinetic analysis of glucoamylase-catalyzed hydrolysis of starch granules from various botanical sources, Biosci. Biotechnol. Biochem., 71, 946 (2007).

8) T. Ikeda, H. Hamada, K. Miki, and M. Senda, Glucose oxidase-immobilized benzoquinonecarbon paste electrode as a glucose sensor, Agric. Biol. Chem., 49, 541 (1985).

9) T. Ikeda, H. Hamada, and M. Senda, Electrocatalytic oxidation of glucose at a glucose oxidase-immobilized benzoquinonemixed carbon paste electrode, Agric. Biol. Chem., 50, 883 (1986).

10) K. Hiromi, Y. Nitta, C. Numata, and S. Ono, 
Subsite affinities of glucoamylase: examination of the validity of the subsite theory, Biochim. Biophys. Acta, 302, 362 (1973).

11) Y.-H. P. Zhang and L. R. Lynd, Toward an aggregated understanding of enzymatic hydrolysis of cellulose: Noncomplexed cellulase systems, Biotechnol. Bioeng., 88, 797 (2004).

12) Y.-H. P. Zhang, M. E. Himmel, and J. R. Mielenz, Outlook for cellulase improvement: Screening and selection strategies, Biotechnol. $A d v ., 24,452$ (2006).

13) H. Tatsumi, H. Katano, and T. Ikeda, Kinetic analysis of enzymatic hydrolysis of crystalline cellulose by cellobiohydrolase using an amperometric biosensor, Anal. Biochem., 357, 257 (2006).

14) N. Cruys-Bagger, H. Tatsumi, K. Borch, and P. Westh, Biosensorer i biomasseforskning (in Danish), Dansk Kemi, 91(3), 10 (2010).

15) N. Cruys-Bagger, G. Ren, H. Tatsumi, M. J. Baumann, N. Spodsberg, H. D. Andersen, L. Gorton, K. Borch, and P. Westh, An amperometric enzyme biosensor for real-time measurements of cellobiohydrolase activity on insoluble cellulose, Biotechnol. Bioeng., in press (2012).

16) N. Cruys-Bagger, J. Elmerdahl, E. Praestgaard, H. Tatsumi, N. Spodsberg, K. Borch, and P. Westh, Pre-steady state kinetics for the hydrolysis of insoluble cellulose by cellobiohydrolase Cel7A, J. Biol. Chem., 287, 18451 (2012).
17) H. Kimoto, M. Akamatsu, Y. Fujii, H. Tatsumi, H. Kusaoke, and A. Taketo, Discoidin domain of chitosanase is required for binding to the fungal cell wall, J. Mol. Micorbiol. Biotechnol., 18, 14 (2010).

18) H. Tatsumi, H. Katano, T. Ikeda, and H. Kimoto, Activity measurement of chitosanase by an amperometric biosensor, Anal. Sci., 25, 825 (2009).

19) 稲垣英典, $N$-アセチルグルコサミンに応答す る電流計測型バイオセンサーの構築，福井県 立大学卒業論文 (2008).

20) 野田太以良, 電気化学測定法を用いるキチン の酵素的加水分解反応の速度解析, 福井県 立大学卒業論文 (2008).

21) L. Murphy, K. Borch, K. C. McFarland, C. Bohlina, and P. Westh, A calorimetric assay for enzymatic saccharification of biomass, Enz. Microb. Technol., 46, 141 (2010).

22) L. Murphy, N. Cruys-Bagger, H. D. Damgaard, M. J. Baumann, S. N. Olsen, K. Borch, S. F. Lassen, M. Sweeney, H. Tatsumi, and P. Westh, Origin of initial burst in activity for Trichoderma reesei endo-glucanases hydrolyzing insoluble cellulose, J. Biol. Chem., 287, 1252 (2012).

23) N. Cruys-Bagger, H. Tatsumi, K. Borch, and P. Westh, Development of isothermal microcalorimetry with in-situ electrochemical biosensors, The $61^{\text {st }}$ Annual Meeting of the International Society of Electrochemistry, Nice, France, Abstract file ‘ise101046’ (2010). 